\title{
Publisher Correction: Inference of RNA decay rate from transcriptional profiling highlights the regulatory programs of Alzheimer's disease
}

\author{
Rached Alkallas ${ }^{1,2}$, Lisa Fish $3,4,5$, Hani Goodarzi ${ }^{3,4,5}$ \& Hamed S. Najafabadi (10) 1,2
}

Correction to: Nature Communications; https://doi.org/10.1038/s41467-017-00867-z; published online: 13 Oct 2017.

The original version of this Article contained an error in Figure 3, where panel d was inadvertently replaced with a duplicate of panel c during typesetting. Also, the legend of Figure 5f incorrectly read ' $310 \mathrm{AD}$ patients (blue dots, $r=-0.4$ ) and 157 non-demented individuals (green dots, $r=-0.1$ )', and should have read ' $310 \mathrm{AD}$ patients (blue dots, $r=-0.1$ ) and 157 non-demented individuals (green dots, $r=-0.4$ )'. Both of these errors have now been corrected in both the PDF and HTML versions of the Article.

Published online: 31 October 2018

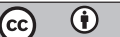

Open Access This article is licensed under a Creative Commons Attribution 4.0 International License, which permits use, sharing, adaptation, distribution and reproduction in any medium or format, as long as you give appropriate credit to the original author(s) and the source, provide a link to the Creative Commons license, and indicate if changes were made. The images or other third party material in this article are included in the article's Creative Commons license, unless indicated otherwise in a credit line to the material. If material is not included in the article's Creative Commons license and your intended use is not permitted by statutory regulation or exceeds the permitted use, you will need to obtain permission directly from the copyright holder. To view a copy of this license, visit http://creativecommons.org/licenses/by/4.0/.

(c) The Author(s) 2018

\footnotetext{
${ }^{1}$ Department of Human Genetics, McGill University, Montreal, QC, H3A OC7, Canada. ${ }^{2}$ McGill University and Genome Quebec Innovation Centre, Montreal, QC, H3A 0G1, Canada. ${ }^{3}$ Department of Biochemistry and Biophysics, University of California, San Francisco, CA 94158, USA. ${ }^{4}$ Department of Urology, University of California, San Francisco, CA 94158, USA. ${ }^{5}$ Helen Diller Family Comprehensive Cancer Center, University of California, San Francisco, CA 94158, USA. Correspondence and requests for materials should be addressed to H.S.N. (email: hamed.najafabadi@mcgill.ca)
} 